\title{
PENDEKATAN STEM UNTUK MENINGKATKAN KETERAMPILAN BERPIKIR KRITIS SISWA PADA MATERI FLUIDA STATIS
}

\author{
I.F. Lestari*, S.N. Muhajir \\ Program Studi Pendidikan Fisika, Fakultas Pendidikan Islam dan Keguruan \\ Universitas Garut, Indonesia \\ Jl. Raya Samarang No. 52A, Garut. \\ E-mail: istifujilestari@uniga.ac.id
}

\begin{abstract}
Abstrak
Penelitian ini bertujuan untuk mengetahui peningkatan keterampilan berpikir kritis siswa SMA melalui pendekatan STEM pada materi fluida statis. Penelitian ini dilakukan di salah satu SMA Negeri di Kabupaten Garut dengan jumlah sampel 40 siswa (18 siswa laki-laki dan 22 siswa perempuan). Jenis penelitian ini adalah pre-eksperimen dengan rancangan one shot pretest-posttest group. Instrumen penelitian berupa soal uraian keterampilan berpikir kritis siswa SMA pada materi fluida statis. Berdasarkan nilai N-Gain diperoleh hasil 0.62 yang termasuk dalam kategori sedang. Peningkatan tertinggi terdapat pada indikator memberi penjelasan sederhana dan peningkatan terendah terdapat pada indikator mengatur strategi dan taktik. Hasil penelitian menunjukkan bahwa pendekatan STEM dapat meningkatan keterampilan berpikir kritis siswa pada materi fluida statis.
\end{abstract}

Kata kunci: Fluida Statis; Keterampilan Berpikir Kritis; Pendekatan STEM

\section{Pendahuluan}

Di abad 21 siswa perlu memiliki keterampilan yang dapat menunjang dirinya agar dapat beradaptasi dengan perubahan zaman terutama di Era 21 (Muhajir, 2019). Salah satunya adalah keterampilan berpikir kritis (Dwyer, 2014; Harahap, 2020). Keterampilan berpikir kritis merupakan keterampilan dasar yang harus dimiliki siswa untuk memecahkan masalah (Lang, 2000). Sehingga siswa dapat mencari beberapa solusi yang tepat berdasarkan akar permasalahannya. Dalam kegiatan pembelajaran keterampilan berpikir kritis perlu dibangun dan dibiasakan, untuk itu perlu adanya rancangan program kegiatan pembelajaran yang memfasilitasi untuk melatihkan keterampilan berpikir kritis pada siswa (Supena, 2021; Kurniawan, 2021). Dalam hal ini guru memiliki peran penting sebagai fasilitator dalam kegiatan pembelajaran.

Berpikir kritis dapat merupakan keterampilan untuk menanggapi suatu permasalahan. Tanggapan yang diberikan dipaparkan dalam bentuk alasan yang mendasar dan logis sehingga dapat digunakan untuk menarik suatu kesimpulan. Dengan kata lain kesimpulan dari tanggapan merupakan suatu alternatif solusi pemecahan yang tepat (Kurniati et al, 2021; Hacioglu, 2021). Keterampilan untuk menemukan solusi yang tepat ini perlu dilatihkan salah satunya adalah dalam kegiatan pembelajaran di sekolah.

Kegiatan pembelajaran yang dilakukan harus disesuaikan dengan teknologi yang berkembang saat ini. Siswa kini lebih dihadapkan pada kemajuan teknologi informasi dalam kehidupan sehari-hari. Untuk itu, dimulai pada abad 19, para pembuat kebijakan, pendidik, dan masyarakat umum seutuhnya memusatkan perhatian pada pengajaran dan pembelajaran sains (Wan et al, 2019; Ab Kadir, et al, 2021). Pada abad 21, pengajaran sains membutuhkan pendekatan yang efisien untuk membantu siswa memperdalam dan menguasai 
pemahaman mereka tentang sains. Salah satu reformasi dalam pengajaran sains adalah melalui pendekatan STEM (Science, Technology, Engineering \& Mathematics) yang dikenal sebagai "Integrated STEM".

STEM merupakan hal yang sedang hangat diperbincangkan terutama di dunia pendidikan. Salah satu alasannya adalah karena tuntutan peradaban yang semakin serba pesat. Belajar dengan pendekatan STEM lebih dari sekadar memperoleh pengetahuan dasar karena memerlukan upaya untuk menghasilkan pengetahuan baru dan merancang solusi inovatif (Goldman, et al 2001; Minshew et al, 2021). Selain itu, STEM juga diyakini mampu untuk melatihkan keterampilan berpikir peserta didik secara mendalam sehingga dapat melihat peluang berdasarkan pengetahuan yang dimiliki dari hasil kegiatan pembelajaran yang bermakna (Juca et al, 2020; Ryoo, J., \& Winkelmann, K, 2021).

Berdasarkan hasil penelitian STEM dapat meningkatkan kemampuan pemecahan masalah fisika siswa pada konsep tekanan hidrostatis (Lestari, 2019). Selain itu, pendekatan STEM juga dapat meningkatkan motivasi belajar, kolaborasi dan keterampilan berpikir kritis siswa. (Kurniati et al, 2021; Hacioglu, 2021; Bulu et al, 2021). Untuk itu dipandang perlu menerapkan sebuah metode pembelajaran yang dapat menunjang dan memfasilitasi juga menggiring siswa untuk berpikir kritis salah satunya adalah dengan pendekatan STEM.

Pendekatan STEM dalam pembelajaran yang digunakan dalam penelitian ini dibatasi pada berfokus isu pada dunia nyata, mengajukan pertanyaan (scientific process), dan mendefinisikan masalah (engineering process), serta engineering design process (design, construct, and test). Siswa merumuskan isu/permasalahan yang diberikan oleh guru dan berkaitan dengan produk teknologi. Siswa mengajukan pertanyaan dan mencoba menjawab pertanyaan disertai alasannya. Siswa merancang solusi permasalahan dengan membuat rancangan teknologi sederhana. Kemudian siswa membuat remodeling produk teknologi sesuai dengan analisis sistem dan konsep yang dipelajari.

Indikator keterampilan berpikir kritis yang dilatihkan dalam penelitian ini merupakan lima indikator umum menurut Ennis (2011). Indikator tersebut yaitu: memberikan penjelasan sederhana (elementary clarification), membangun keterampilan dasar (basic support), menyimpulkan (inference), memberikan penjelasan lanjut (advanced clarification), dan mengatur strategi dan taktik (strategies and tactic).

\section{Metode Penelitian}

Metode penelitian yang digunakan dalam penelitian ini adalah metode pre eksperimen dengan rancangan one shot pretest-posttest group. Pemilihan metode ini karena hanya ingin mengetahui dampak dari penerapan pendekatan STEM dalam meningkatkan keterampilan berpikir kritis siswa SMA pada materi fluida statis tanpa menguji efektivitasnya jika dibandingkan dengan perlakukan lain (Cresswell, 2014; Fraenkel, 2012).

Penelitian ini terdiri dari tiga tahapan. Tahapan pertama siswa diberikan tes awal (pretest) keterampilan berpikir kritis sebelum diberikan perlakuan. Tahapan kedua siswa mendapat perlakuan pembelajaran (treatment) dengan menerapkan pendekatan STEM pada materi fluida statis, yaitu konsep tekanan hidrostatis, hukum Pascal dan hukum Archimedes. Tahapan ketiga siswa diberikan tes akhir (posttest) keterampilan berpikir kritis siswa. Rancangan penelitan dapat dilihat pada Tabel 1.

Tabel 1. Rancangan Penelitian

\begin{tabular}{ccc}
\hline Pretest & Treatment & Posttest \\
\hline 0 & $\mathrm{X}$ & 0 \\
\hline
\end{tabular}

Keterangan:

O: Pretest dan posttest untuk mengukur keterampilan berpikir kritis siswa

$\mathrm{X}$ : Penerapan pendekatan STEM pada materi fluida statis 
Populasi penelitian ini meliputi seluruh siswa program Ilmu Alam di salah satu SMA di kabupaten Garut dengan jumlah sampel 40 siswa (18 siswa laki-laki dan 22 siswa perempuan). Teknik pengambilan sampel dengan cara pengambilan kelas secara acak (random class). Teknik tersebut dilakukan mengingat tidak memungkinkan jika diambil siswa secara acak dengan merubah formasi siswa yang sudah ada di kelas tersebut. Sehingga diambil satu kelas secara acak untuk dijadikan subjek penelitian.

Instrumen yang digunakan berupa tes keterampilan berpikir kritis berbentuk soal uraian pada materi fluida statis yang mencakup konsep tekanan hidrostis, prinsip hukum Pascal, dan hukum Archimedes. Masingmasing soal disusun berdasarkan indikator keterampilan berpikir kirtis (Ennis, 2011). Validitas instrumen menggunakan validitas konstruk yang menunjukkan kesesuaian soal, kunci jawaban, rubrik penskoran dan kalimat soal yang digunakan. Reliabilitas instrumen sebesar 0,79 dengan kategori tinggi. Peningkatan keterampilan berpikir kritis siswa diukur dengan menggunakan Gain yang dinormalisasi (N-Gain). N-Gain yang diperoleh kemudian diinterpretasikan berdasarkan kategori menurut Hake (1999) yang disajikan pada Tabel 2.

Tabel 2. Interpretasi Nilai $N$-Gain

\begin{tabular}{cc}
\hline $\mathbf{N}-$ Gain (N) & Kategori \\
\hline $\mathrm{N}<0,3$ & rendah \\
\hline $0,3 \leq \mathrm{N}<0,7$ & sedang \\
\hline $0,7 \leq \mathrm{N}$ & tinggi \\
\hline
\end{tabular}

\section{Hasil dan Pembahasan}

Data keterampilan berpikir kritis siswa diperoleh dari rata-rata nilai pretest, posttest, dan Gain yang dinormalisasi ( $N$-Gain). Berdasarkan hasil penelitian diperoleh rata-rata nilai pretest sebesar 24 , nilai posttest sebesar 71, maka diperoleh nilai Gain 47 (nilai maksimum 100). Nilai Gain dinormalisasi sehingga menghasilkan $\mathrm{N}$-Gain sebesar 0,62 (nilai maksimum 1). Jika dikonfirmasi ke dalam kategori Hake (1999), maka nilai $\mathrm{N}$-Gain keterampilan berpikir kritis siswa sebagai dampak penerapan pendekatan STEM termasuk dalam kategori sedang.

Hasil penelitian ini menunjukkan peningkatan keterampilan berpikir kritis sebagai dampak penerapan pendekatan STEM pada materi fluida statis. Hal ini dapat disebabkan karena selama pembelajaran pada materi fluida statis, siswa dilatih untuk belajar berpikir tingkat tinggi. Siswa mengkonstruksi sendiri pengetahuannya dari berbagai isu dan pengalamannya. Siswa menghubungkan pengetahuan lama dengan pengetahuan baru yang diperoleh dalam kegiatan pembelajaran dengan pendekatan STEM (Arnold, S., Warner, W.J., \& Osborne, E.W., 2006). Siswa mengidentifikasi berbagai permasalahan dalam isu STEM yang diberikan dan belajar menyimpulkan suatu konsep atau kejadian yang berkaitan dengan fluida statis. Hal ini senada dengan yang diungkapkan Ennis (1985), bahwa berpikir kritis yaitu mampu memberikan alasan, berpikir secara reflektif, dan fokus untuk memutuskan apa yang akan dilakukan atau apa yang diyakini.

Faktor lain yang dapat menyebabkan peningkatan keterampilan berpikir kritis diantaranya karena dalam pembelajaran dengan pendekatan STEM banyak melakukan kegiatan hands-on yang melibatkan siswa dalam pembelajaran. Kegiatan tersebut pada saat siswa bersama-sama dalam merancang dan membuat produk teknologi sederhana. Chanchaicaovivat, dkk. (2009), menyatakan bahwa kegiatan hands-on dapat menyebabkan pemahaman yang bermakna antara siswa sebagai pembelajar dan fenomena yang terjadi di dalam kehidupan nyata sehingga dapat meningkatkan keterampilan berpikir kritis.

Keterampilan berpikir kritis siswa yang diukur dalam penelitian ini terdiri dari lima indikator (Ennis, 2011). Persentase rata-rata skor pretest-posttest tiap indikator disajikan pada Gambar 1. Berdasarkan Gambar 1, dapat dilihat bahwa persentase rata-rata skor pretest dibandingkan posttest selalu mengalami peningkatan 
tiap indikator. Hal ini semakin menguatkan bahwa pendekatan STEM dapat meningkatkan keterampilan berpikir kritis siswa, termasuk dalam setiap indikator.

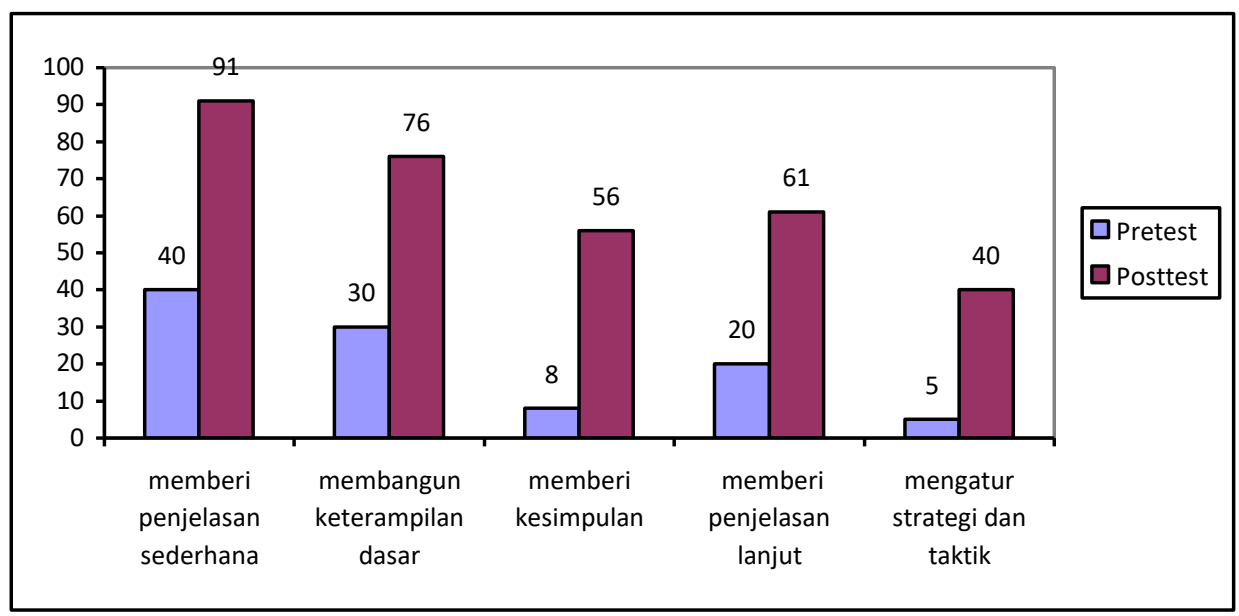

Gambar 1. Persentase rata-rata skor pretest-posttest siswa tiap indikator keterampilan berpikir kritis

Adapun skor $N$-Gain untuk tiap indikator keterampilan berpikir kritis siswa disajikan pada Gambar 2. Berdasarkan Gambar 2, dapat dilihat bahwa $N$-Gain seluruh indikator keterampilan bepikir kritis siswa mengalami peningkatan. Peningkatan tertinggi terdapat pada indikator memberikan penjelasan sederhana $(0,84)$, sedangkan peningkatan terendah terdapat pada indikator mengatur strategi dan taktik $(0,37)$.

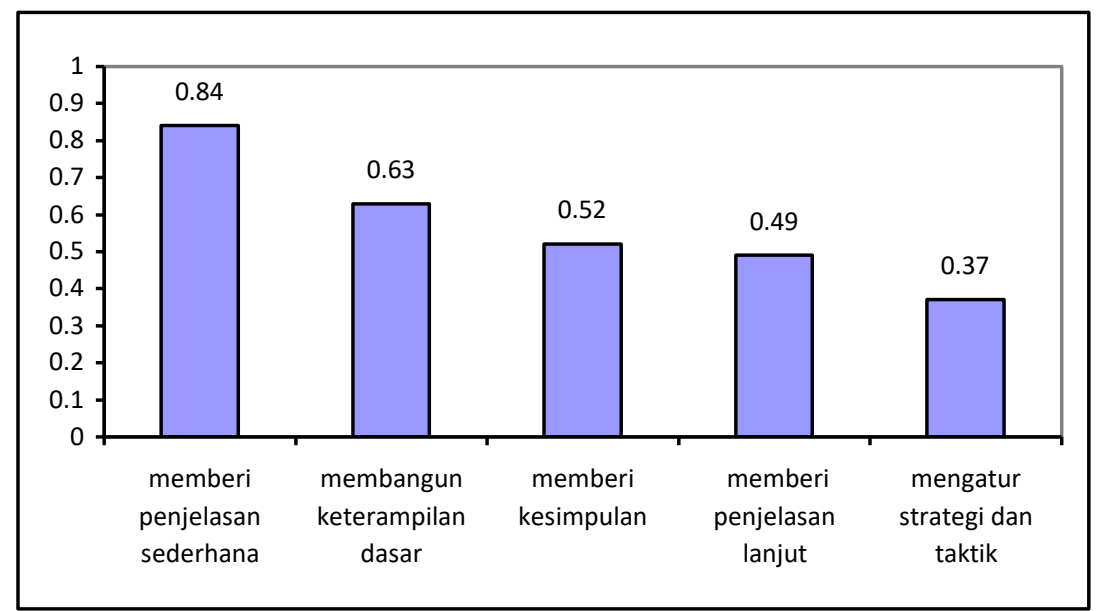

Gambar 2. Rata-rata N-Gain Keterampilan Berpikir Kritis Siswa Tiap Indikator

Indikator memberikan penjelasan sederhana yang digunakan dalam penelitian ini terdiri dari dua sub indikator, yaitu memfokuskan dan menjawab pertanyaan serta menganalisis argumen dengan alasan. Indikator memberikan penjelasan sederhana dilatih dengan pendekatan STEM dalam tahap scientific process. Siswa dilatihkan untuk untuk memfokuskan pertanyaan terhadap berbagai masalah yang dihadapi, diantaranya pada isu banjir karena sumbatan alian sungai. Siswa mengajukan pertanyaan cara membuat alat yang dapat mengangkat atau memindahkan tumpukan sampah yang menyumbat aliran sungai. Setelah siswa mengajukan pertanyaan, guru membimbing siswa untuk menjawab pertanyaannya sendiri berdasarkan hasil pengamatan terhadap demonstrasi yang dilakukan oleh guru. Hasil ini mendukung penelitian yang dilakukan Duran (2012), bahwa STEM dapat meningkatkan keterampilan berpikir kritis siswa SMA pada kemampuan memberi alasan. Contoh pertanyaan dan jawaban siswa terkait materi fluida pada penerapan prinsip hukum Pascal dapat dilihat pada Gambar 3. 


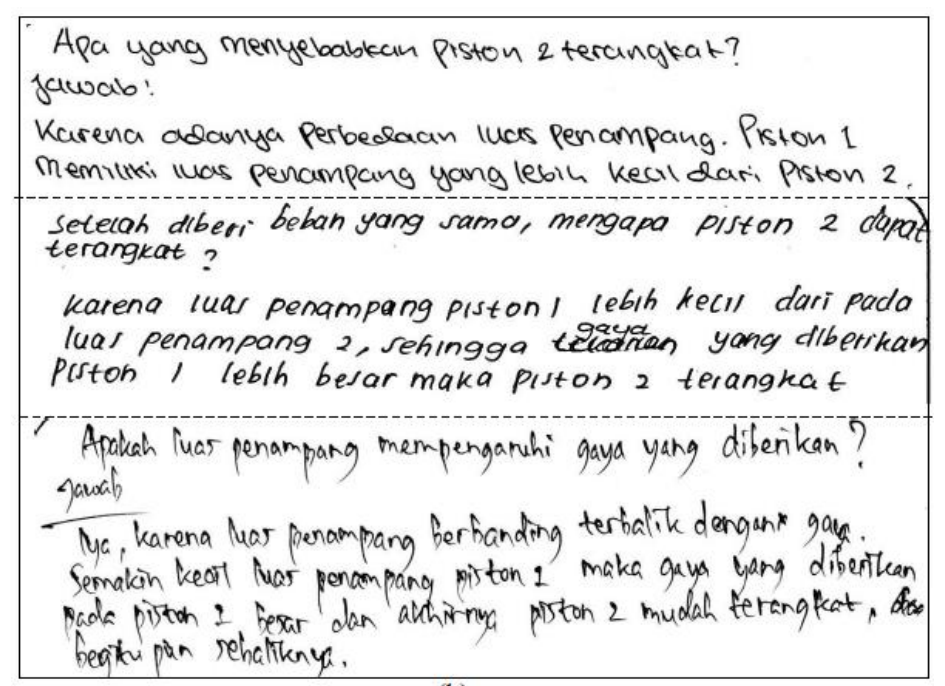

Gambar 3. Pertanyaan dan jawaban siswa terkait materi fluida statis

Peningkatan keterampilan berpikir kritis terendah terdapat pada indikator mengatur stategi dan taktik. Siswa diharapkan dapat berpikir untuk meninjau dan menentukan suatu tindakan. Indikator mengatur strategi dan taktik dilatihkan pada pada tahapan design and construct. Pada tahap ini siswa merancang dan membuat suatu produk teknologi sederhana berdasarkan isu permasalahan yang dihadapi sebelumnya. Guru melatihkan indikator mengatur strategi dan taktik dengan cara menginstruksikan siswa untuk meninjau kelemahan atau kelebihan rancangan dan produk teknologi sederhana yang mereka buat. Salah satu rancangan dan produk teknologi yang mereka buat diantaranya lengan hidrolik sederhana, dapat dilihat pada Gambar 4.
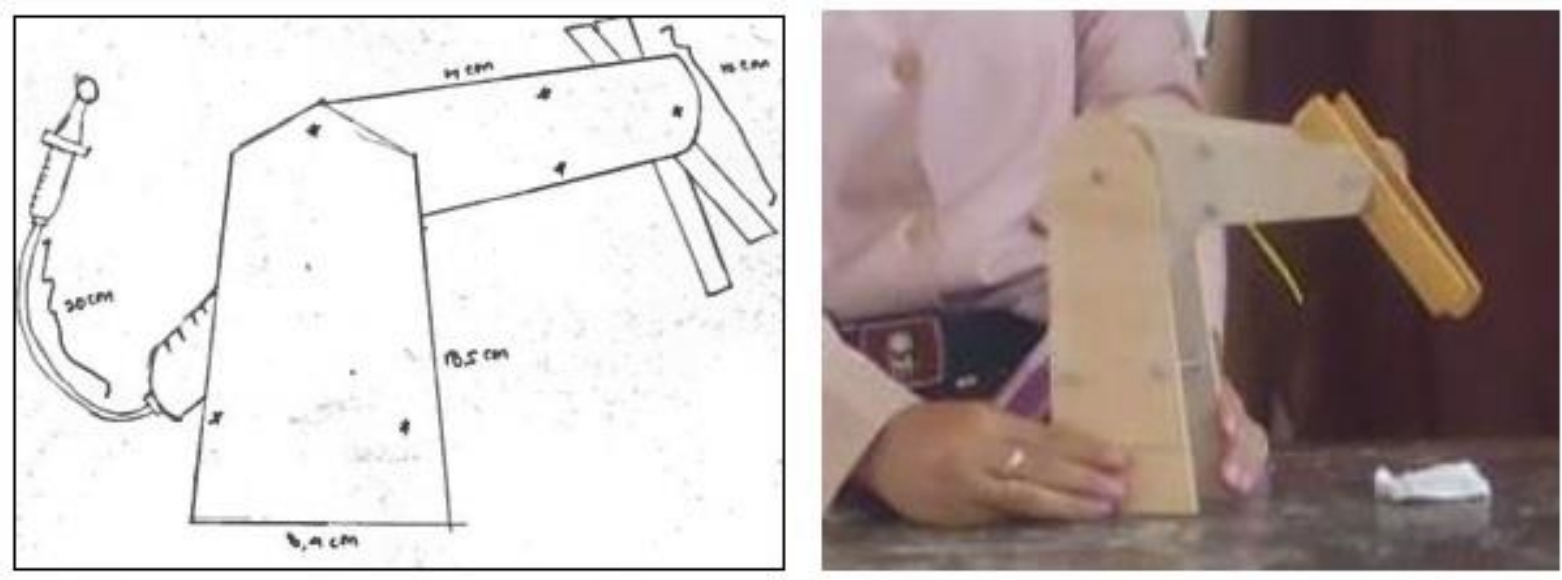

Gambar 4. Rancangan dan Produk Lengan Hidrolik Sederhana Siswa

Siswa mengemukakan kekurangan produk lengan hidrolik sederhana yang mereka buat. Lengan hidrolik hanya dapat bergerak ke atas dan ke bawah, sehingga hanya dapat digerakkan untuk mengangkat benda berat tanpa dapat memindahkan benda tersebut ke kiri atau kanan. Guru menginstruksi untuk meninjau kembali produk yang mereka buat dan melatih siswa untuk berpikir menemukan solusi untuk mengatasinya. Namun, siswa belum dapat mengungkapkan staregi atau taktik untuk mengatasi kekurangan produk tersebut. Hal ini dapat memperkuat alasan rendahnya peningkatan indikator mengatur strategi dan taktik.

Jika dianalisis lebih lanjut pada rancangan lengan hidrolik sederhana yang siswa buat, rancangan tersebut hanya menggunakan dua buah spuit dan satu selang. Padahal untuk dapat memindahkan suatu benda, dibutuhkan gerakan ke atas-bawah dan depan-belakang. Hal ini dapat menunjukkan bahwa kemampuan siswa dalam mengatur strategi dan taktik belum maksimal. 


\section{$4 \quad$ Kesimpulan}

Berdasarkan hasil penelitan dan pembahasan maka dapat disimpulkan penerapan pendekatan STEM dapat meningkatkan keterampilan berpikir kritis siswa pada materi fluida statis. Rata-rata nilai $\mathrm{N}$-Gain peningkatan keterampilan berpikir kritis siswa pada materi fluida statis sebesar 0,62 yang termasuk dalam kategori sedang. Peningkatan keterampilan berpikir kritis tertinggi terdapat pada indikator memberi penjelasan sederhana dan peningkatan terendah terdapat pada indikator mengatur strategi dan taktik.

\section{Ucapan Terima Kasih}

Ucapan terima kasih dan penghargaan disampaikan penulis atas dukungan dari Fakultas Pendidikan Islam dan Keguruan Universitas Garut.

\section{Daftar Pustaka}

Ab Kadir, W., Huda, W. N., Abdullah, N. S. Y., \& Mustapha, I. R. (2021). The Effectiveness of Form Four STEM-Based Physics Interactive Laboratory (I-Lab) by Employing Isman Instructional Design Model. Turkish Online Journal of Educational Technology-TOJET, 20(2), 140-145.

Bulu, V. R., \& Tanggur, F. (2021). The Effectiveness of STEM-Based PjBL on Student's Critical Thinking Skills and Collaborative Attitude. Al-Jabar: Jurnal Pendidikan Matematika, 12(1), 219-228.

Creswell, J.W. (2014). Research Design: Quantitative, Qualitative, and Mixed Methods Approaches. United Stated of America: SAGE Publications.

Chanchaichaovivat, A., Panijpan, B., dan Ruenwongsa, P. (2009). Enhancing Conceptual Understanding and Critical Thinking with Experiential Learning: A Case Study with Biological Control. Asian Journal of Food and Argo-Industry. Special Issue, S424-S443.

Duran, M., dan Sendag, S. (2012). A Preliminary Investigation into Critical Thinking Skills of Urban High School Students: Role of an IT/STEM Program. Scientifif Research, 3(2), hlm. 241-250.

Dwyer, C. P., Hogan, M. J., \& Stewart, I. (2014). An integrated critical thinking framework for the 21st century. Thinking skills and Creativity, 12, 43-52.

Ennis. (2011). The Nature of Critical Thinking: An Outline of Critical Thinking Dispositions and Abilities. [Online]. Diakses dari http://faculty.education.illinois.edu/rhennis/documents/TheNatureofCritical Thinking_51711_000.pdf

Fraenkel, J.R., Wallen, N.E., dan Hyun, H.H. (2012). How to Design and Evaluate Research in Education Eight Edition. New York: McGrow Hill Company.

Goldman, C. A., \& Massey, W. F. (2001). The PhD factory: Training and employment of science and engineering doctorates in the United States. Anker

Hacioglu, Y., \& Gulhan, F. (2021). The Effects of STEM Education on the Students' Critical Thinking Skills and STEM Perceptions. Journal of Education in Science, Environment and Health, 7(2), 139-155.

Hake, R.R. (1999). Analyzing Change/Gain Score. American Educational Research Associations Division Measurement and Research Methodology. Diakses dari http://www.physics.indiana.edu/ $\sim$ sdi/AnalyzingChange-Gain.pdf

Harahap, L. J., Ristanto, R. H., \& Komala, R. (2020). Evoking 21st-Century Skills: Developing instrument of critical thinking skills and mastery of ecosystem concepts. Tadris: Jurnal Keguruan dan Ilmu Tarbiyah, 5(1), 27-41.

Juca-Aulestia, M., Zúñiga-Tinizaray, F., Pozo-Vinueza, M., Malla-Alvarado, F., Cáceres-Mena, M., Almendariz-Pozo, P., \& Román-Robalino, D. (2021). Instrumentation, Implementation and Tools in STEM-STEAM Education: A Systematic Literature Review. In World Conference on Information Systems and Technologies (pp. 183-194). Springer, Cham. 
Kurniati, R. D., Andra, D., \& Distrik, I. W. (2021). E-module development based on PBL integrated STEM assisted by social media to improve critical thinking skill: A preliminary study. In Journal of Physics: Conference Series (Vol. 1796, No. 1, p. 012077). IOP Publishing.

Kurniawan, T. T., \& Utaminingsih, S. (2021, March). Analysis of 4C-Based HOTS Assessment Module on Critical Thinking Ability. Journal of Physics: Conference Series (Vol. 1823, No. 1, p. 012101). IOP Publishing.

Lang, D. (2000). Critical Thinking in Web Courses: An oxymoron? Syllabus, 14(2), 20- 24.

Lestari, I.F. (2019). Pendekatan Science, Technology, Engineering, and Mathematic (STEM) untuk Meningkatkan Kemampuan Pemecahan Masalah Fisika Siswa pada Konsep Tekanan Hidrostatis. Jurnal Pendidikan Universitas Garut, Vol. 13 (1), hlm. 103-109.

Minshew, L. M., Olsen, A. A., \& McLaughlin, J. E. (2021). Cognitive Apprenticeship in STEM Graduate Education: A Qualitative Review of the Literature. AERA Open, 7, 23328584211052044.

Muhajir, S. N., Utari, S., \& Suwarma, I. R. (2019). How to develop test for measure critical and creative thinking skills of the 21st century skills in POPBL?. In Journal of Physics: Conference Series (Vol. 1157, No. 3, p. 032051). IOP Publishing.

Supena, I., Darmuki, A., \& Hariyadi, A. (2021). The Influence of 4C (Constructive, Critical, Creativity, Collaborative) Learning Model on Students' Learning Outcomes. International Journal of Instruction, 14(3), 873-892.

Ryoo, J., \& Winkelmann, K. (2021). Innovative Learning Environments in STEM Higher Education: Opportunities, Challenges, and Looking Forward.

Wan Ab Kadir,W.N.H., Abdullah, N. S. Y., \& Mustapha, I.R (2019). The Application Of The Fuzzy Delphi Technique On A Component Of Development Of Form Four STEM-Based Physics Interactive Laboratory (I-Lab). International Journal Of Scientific \& Technology Research, 8(12), 2918-2912. 